\title{
Ground beetle assemblages of dolomitic grasslands in Hungary
}

\author{
Csaba Kutasi \& Győző Szél
}

Kutasi, Cs. \& Szél, Gy. 2006: Ground beetle assemblages of dolomitic grasslands in Hungary. - Entomol. Fennica 17: 253-257.

The carabid assemblages of dolomitic grasslands were investigated in the Transdanubian Mountains in Central Hungary using pitfall trapping between 1988 and 2005. A total of 2515 indvidual adult carabids, belonging to 65 species were collected from five localities. The most abundant species were Calathus ambiguus (24.5\%), C. cinctus (16.8\%) and C. fuscipes (8.4\%). Rare species were Amara proxima, A. sollicita, Cymindis axillaris, $C$. variolosa, Licinus cassideus and Masoreus wetterhallii. The seasonal activity of adult Carabus hungaricus is given.

C. Kutasi, Department of Zoology, Natural History Museum of Bakony Mountains, H-8420 Zirc, Rákóczi tér 1, Hungary; E-mail: entomologia@bakonymuseum.koznet.hu

G. Szél, Department of Zoology, Hungarian Natural History Museum, H-1088 Budapest, Baross u. 13, Hungary; E-mail: szel@zoo.zoo.nhmus.hu

Received 14 December 2005, accepted 8 June 2006

\section{Introduction}

The insect fauna of the dolomitic grasslands of the southern slopes of mountains in Hungary is important for the conservation of biodiversity, because this type of habitat is home to numerous rare and/or relict species. The most valuable are the thermophilous species living in the Mediterranean and the Caucasus area and at the northern and western extent of range in Hungary.

Pitfall trapping was carried out in the Transdanubian Mountains of Central Hungary. Former investigations in Buda Mountains were focused on the habitat selection of the ground beetles during dolomitic succession (Báldi 1990, Báldi \& Ádám 1991, Waliczky 1991), whilst earlier investigation in the Bakony Mountains was designed to monitor the carabid fauna (Kutasi et al. 2000). There are no comprehensive data about the species composition of ground beetles of dolomitic grassland in Hungary. The most char- acteristic and frequent carabids of dolomitic slopes of one locality, the Odvas-hegy (Buda Mountains) have been published (Szél \& Ádám 1992).

Since there are few papers dealing with the fauna of dolomitic grasslands, the aim of our studies was to explore the ground beetle fauna of such grasslands in several areas of Hungary, to investigate the species composition and the dominance relations of assemblages.

\section{Material and methods}

The samples were collected with pitfall traps at 10 sites (5 localities, 2 sites at each) of dolomitic grasslands representing three regions of Hungary (Bakony Mountains, Vértes Mountains and Buda Mountains) between 1988 and 2005. Three localities were investigated at the Bakony Mountains, Litér, Mogyorós-hegy ( $47^{\circ} 06^{\prime} 05^{\prime \prime} \mathrm{N}, 18^{\circ} 01^{\prime} 45^{\prime \prime}$ 
Table 1. Carabid catches, Berger-Parker dominance index values of the carabid assemblages, standardized abundance $(n)$ trap * year), and eight most abundant species of dolomitic grassland sites in Hungary. Samples sorted according to three mountain areas (Bakony, Vértes and Buda) and sampled habitats (Grass $=$ grassland, Steppe $=$ steppe meadow, Grass $/$ mead = grassland/meadow habitat).

\begin{tabular}{|c|c|c|c|c|c|c|c|c|c|c|}
\hline & \multicolumn{6}{|l|}{ Bakony } & \multicolumn{2}{|l|}{ Vértes } & \multicolumn{2}{|l|}{ Buda } \\
\hline & \multicolumn{2}{|c|}{ Mogyorós-hegy } & \multicolumn{2}{|c|}{ Ugri-hegy } & \multicolumn{2}{|c|}{ Külsö-hegy } & \multicolumn{2}{|l|}{ Bucka } & \multirow{2}{*}{$\begin{array}{l}\text { Odvas- } \\
\text { hegy } \\
\text { Grass/ } \\
\text { mead }\end{array}$} & \multirow{2}{*}{$\begin{array}{l}\text { Török- } \\
\text { ugrató } \\
\text { Grass/ } \\
\text { mead }\end{array}$} \\
\hline & Grass & Steppe & Grass & Steppe & Grass & Steppe & Grass & Steppe & & \\
\hline Sampling period & 1997-01 & 1997-01 & 1997-01 & $1997-01$ & 1997-01 & 1997-01 & 2003-04 & 2003-04 & 1988 & 2005 \\
\hline No. of traps & 15 & 15 & 15 & 15 & 15 & 15 & 20 & 8 & 108 & 27 \\
\hline No. individuals & 174 & 75 & 340 & 202 & 530 & 604 & 65 & 203 & 281 & 41 \\
\hline No. species & 18 & 16 & 27 & 26 & 33 & 37 & 13 & 12 & 27 & 7 \\
\hline Berger-Parker index & 0.21 & 0.31 & 0.4 & 0.18 & 0.6 & 0.19 & 0.55 & 0.44 & 0.42 & 0.39 \\
\hline $\begin{array}{l}\text { Standardized } \\
\text { no. individuals }\end{array}$ & 2.32 & 1 & 4.53 & 2.7 & 7.06 & 8.05 & 1.62 & 12.7 & 2.6 & 1.52 \\
\hline Calathus ambiguus & 17 & - & 40 & 2 & 60 & 19 & 4.6 & 1 & 0.4 & 17 \\
\hline Calathus cinctus & 18 & 16 & 26 & 16 & 9.6 & 12 & 55 & 44 & - & 39 \\
\hline Calathus fuscipes & 21 & 14 & 6.5 & 17 & 0.2 & 4 & 23 & 31 & - & 26.8 \\
\hline Carabus hungaricus & 19 & 31 & 0.3 & - & - & 5.4 & - & - & 4.3 & - \\
\hline Harpalus anxius & - & 1.3 & 3.5 & 18 & 7.7 & 14 & 3 & - & - & - \\
\hline Harpalus subcylindricus & - & - & 1.2 & 8.4 & 1.3 & 12 & - & 4 & - & - \\
\hline Licinus cassideus & 1.7 & - & 0.6 & - & 0.2 & - & 1.5 & - & 7.1 & - \\
\hline Zabrus spinipes & - & 2.7 & - & - & - & 0.5 & - & - & 42 & - \\
\hline
\end{tabular}

E), Királyszentistván, Külső-hegy $\left(47^{\circ} 05^{\prime} 57^{\prime}\right.$ N , $\left.18^{\circ} 02 ' 26^{\prime \prime} \mathrm{E}\right)$ and Vilonya, Ugri-hegy ( $47^{\circ}$ $07^{\prime} 47^{\prime}$ N N, $18^{\circ} 05^{\prime} 17^{\prime}$ ' E). At the Vértes Mountains, Csákberény, Bucka ( $47^{\circ} 21^{\prime} 04^{\prime \prime} \mathrm{N}, 18^{\circ} 21^{\prime}$ 30 " E) and in the Buda Mountains, two locations at Budaörs, Odvas-hegy $\left(47^{\circ} 28^{\prime} 05^{\prime \prime} \mathrm{N}, 18^{\circ} 56^{\prime}\right.$ $48^{\prime \prime}$ E) and Törökugrató $\left(47^{\circ} 27^{\prime} 30^{\prime \prime} \mathrm{N}, 18^{\circ} 55^{\prime}\right.$ 27 ' E) were studied. The main plant associations comprised open (Seseli leucospermo-Festucetum pallentis) or closed (Festuco pallentiBrometum pannonici) dolomitic grassland, and dolomitic steppe meadow (ChrysopogonoCaricetum humilis).

The circumstances and intensity of collecting were different in the three regions. A total of 30 pitfall traps were used at each site in 1997-2001 at the Bakony Mountains, 28 pitfall traps in 2003-2004 at the Vértes Mountains, 108 pitfall traps in 1988, and 27 pitfall traps in 2005 at the Buda Mountains The number of the traps was set according to the length of the study period to ensure the maximum number of species from the given area (the shorter the period, the higher the number of traps). The traps (plastic cups of $8 \mathrm{~cm}$ diameter and $12 \mathrm{~cm}$ depth, partly filled with $40 \%$ ethylene glycol) were placed $5 \mathrm{~m}$ from each other and covered with a square aluminium cover to protect the trap content from rain, litter and disturbance by small vertebrates.

The traps were checked and material collected every two weeks between April and October. The samples from each trap were handled separately, stored at $-18^{\circ} \mathrm{C}$, sorted and identified by the authors using Hưrka's (1996) keys. The material is deposited in the collections of the Natural History Museum of Bakony Mountains (Zirc, Hungary) and of the Hungarian Natural History Museum (Budapest).

Comparison of the carabid assemblages of the investigated localities was made by hierarchical clustering (Single-link) of the Jaccard Index. Calculations were made by the Syntax 2000 computer package (Podani 1997). The chorological types were used according to Hưrka (1996) and the ecological characteristics were adopted from Kirschenhofer (1989). 


\section{Results}

A total of 2515 individuals belonging to 65 species were collected. The percentage of Palaearctic and West Palaearctic species was relatively high $(41.5 \%)$. The sampled species included 34 xerophilic $(52.3 \%), 18$ thermophilic (18.5\%), and 8 psammophilic (12.3\%) species. The assemblage comprised $26 \%$ stenotopic species.

The bulk of the species belonged to the genera Harpalus (14) and Amara (10). The most abundant species were Calathus ambiguus (24.5\%), C. cinctus $(17 \%)$ and $C$. fuscipes $(8.7 \%)$. Other dominant species were: Carabus hungaricus, Harpalus anxius, H. subcylindricus and Zabrus spinipes. The species number collected in the individual dolomitic grassland locations varied between 7 and 37, while the abundance of the ground beetles was low. The average number of individuals per trap * year varied between 1 and 12.7 (Table 1). The dominant species of the study sites are also presented in Table 1.

The assemblages of the different localities were compared using the Jaccard Index (Fig 1). The hierarchical classification showed that the carabids were divided into distinct regions. According to these results, the most frequent species of the Bakony Mountains were Calathus ambiguus, C. cinctus and Harpalus anxius. C. cinctus and $C$. fuscipes were the most frequent species at the Vértes Mountains, while $C$. cinctus and Zabrus spinipes were most abundant at the Buda Mountains.

The species similarity of carabid assemblages in the different regions was low, with only eight species occurring in all localities: Calathus ambiguus, C. cinctus, C. fuscipes, Harpalus pumilus, $H$. roubali, $H$. rubripes, $H$. tardus and Licinus cassideus. A total of 23 carabid species (35.4\%) occurred only in one locality. Rare species found in the study area included Amara proxima, A. sollicita, Cymindis axillaris, C. variolosa, Licinus cassideus and Masoreus wetterhallii. Carabus hungaricus is one of the rarest species in Hungary, and seasonal dynamics of this species has not previously been published (Turin et al. 2003; Fig 2). C. hungaricus has a predominantly autumn activity, although it occurs in dolomitic grasslands from the beginning of June. The second peak of activity, from the end

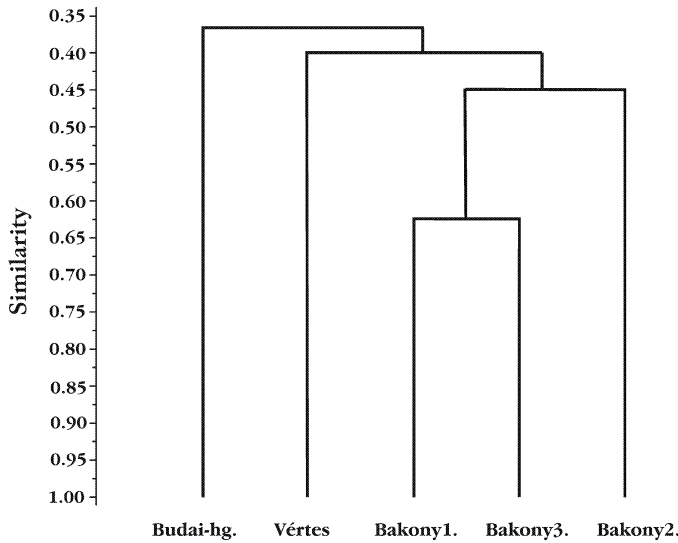

Fig. 1. Dendrogram of similarity, based on the Jaccard Index, of carabid assemblages in dolomitic grassland sites. Abbreviations: Budai-hg: Budaörs, Vértes: Csákberény, Bakony1: Királyszentistván, Bakony2: Litér, Bakony3: Vilonya.

of August to the end of October, is the main one. The highest number of specimens was observed in the second half of September.

\section{Discussion}

The examinations were carried out in ten dolomitic grasslands in five localities representing the most extensive dolomitic regions of Hungary (Bakony, Vértes and Buda Mountains). It can be concluded that the number of specimens and species of carabid asssemblages are very low

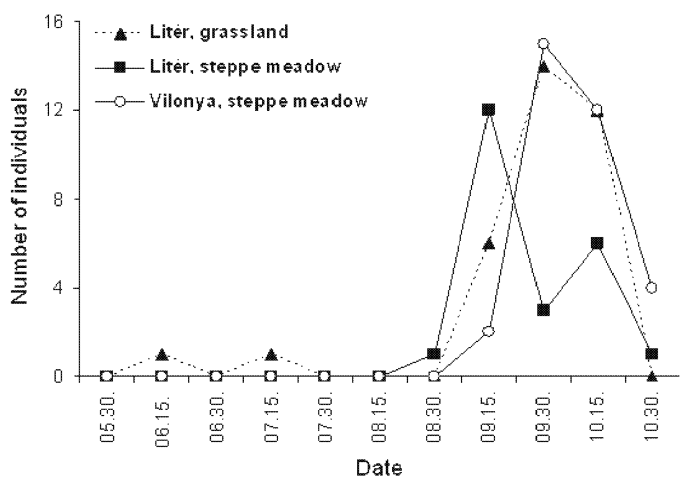

Fig. 2. Seasonal fluctuations of Carabus hungaricus in dolomitic grasslands of Bakony Mountains [19972001; 15 pitfall traps (total number of $C$. hungaricus catches per dates, all years and traps summed)]. 
in these habitats, and contains several rare species.

Waliczky (1991) found 37 ground beetle species from the Buda Mountains (Nagykovácsi) in dolomitic rock swards and turkey oak forest. Of these, 21 species were also found by us (these are members of species communities of dry, open steppes); the remaining 16 belong to forest communities. From the Bakony Mountains, nearby the area investigated by us, Kutasi (1998) mentions 14 carabid species, of which all but Pterostichus incommodus were found in our study. A number of species of the dolomitic regions do occur in limestone rock sward, too (Horvatovich 1989, 2000). The faunistic overlap with the sandy grasslands is also considerable: several species occur in both areas. The faunistic similarity is at least partly due to the good heat conductivity of the ground.

Some rare species, such as Licinus cassideus and Amara sollicita, also occur in limestone rock swards (Horvatovich 1989, 2000), while Carabus hungaricus, L. cassideus, Masoreus wetterhallii and Zabrus spinipes are typical inhabitants of the sandy regions of the Great Hungarian Plain (Ádám \& Merkl 1986). These thermophilous species are distributed mainly in the southern part of Europe, in Asia Minor and/or in North Africa. Carabus hungaricus, which proved a dominant species in some samples, is strictly protected in Hungary since 2001 and a species of European community interest within Natura 2000.

Of the species we classified as common, Calathus fuscipes and Zabrus spinipes were also common during an earlier study in the Buda Mountains (Waliczky 1991). Zabrus spinipes occurs not only in sandy grasslands but also in parks (Kutasi \& Szél 2000) and humid areas (forest edges and depressions with reeds and willows) (Kutasi 1998, Szél \& Kutasi 2003).

Of the rare species, Masoreus wetterhallii and Cymindis axillaris were found in earlier studies on dolomitic rock sward (Waliczky 1991).

The most abundant species have their activity peaks in autumn and two of these, viz. Calathus ambiguus and $C$. fuscipes, can be found in great numbers on arable land (Thiele 1977, Lövei \& Sárospataki 1990), apple orchards (Kutasi et al. 2004) and sandy areas (Szél \& Kutasi 2005).
Calathus ambiguus is the qualitative indicator of sandy soil type in Germany (Müller-Motzfeld 1989), while C. fuscipes is significantly associated with sandy soil in arable fields (Irmler, 2003). In addition to the two dominant species ( $C$. ambiguus and C. fuscipes), almost half of the collected species are frequent in agricultural areas, including Agonum dorsale, Amara aenea, A. familiaris, Brachinus explodens, Calathus erratus, Harpalus distinguendus, H. griseus, H. rufipes, H. serripes, H. smaragdinus and Trechus quadristriatus (Horvatovich \& Szarukán 1986, Kutasi et al. 2004). The same phenomenon has earlier been found in limestone rock sward and the neighbouring agricultural fields (Horvatovich 1989, 2000).

The carabid communities of the Hungarian dolomitic steppes show similarity to those of other vegetation-poor, bare areas. The occurence of many thermophilous and xerotherm species can be explained by the good heat conductivity of the soil. Although a significant proportion of these species also occurs in agricultural/cultivated areas, we found several rarities with high protection value. In Hungary, the dolomitic rock swards are endangered by many activities, such as mining, illegal trash deposits and motor sports. Our work underlines that the protection of these habitats is also important for entomological reasons.

Ackowledgements. This research was supported by the National R\&D Programme: "The origin and genesis of the fauna of the Carpathian Basin: diversity, biogeographical hotspots and nature conservation significance", contract no: 3B023-04. We thank two anonymous reviewers and G. Lövei for comments on an earlier verison of this paper.

\section{References}

Ádám, L. \& Merkl, O. 1986. Adephaga of the Kiskunság National Park, I. Carabidae (Coleoptera). - In: Mahunka, S. (ed.): The fauna of the Kiskunság National Park, I: 119-142. Akadémiai Kiadó, Budapest.

Báldi, A. 1990. Species richness, abundance and diversity of beetles (Coleoptera) in relation to ecological succession. - Folia Entomologica Hungarica 51: 17-24.

Báldi, A. \& Ádám, L. 1991. Habitat selection of grounddwelling beetles during dolomitic succession. - Annales Historico-Naturales Musei Nationalis Hungarici 83: $245-251$.

Horvatovich, S. 1989. A Villányi-hegység futóbogarai (Coleoptera: Carabidae). (The Carabidae (Coleop- 
tera) of Villány Mountains, South Hungary). - A Janus Pannonius Múzeum Évkönyve 33: 19-25.

Horvatovich, S. 2000. A Villányi-hegység futóbogarai (Coleoptera: Carabidae) II. (The carabid beetles ( $\mathrm{Co}-$ leoptera: Carabidae) of the Villány Hills, South Hungary II.) - Dunántúli Dolgozatok Természettudományi Sorozat 10: 175-187. [In Hungarian.]

Hůrka, K. 1986. Carabidae of the Czech and Slovak Republics. - Kabourek, Zlín. 565 pp.

Irmler, U. 2003. The spatial and temporal pattern of carabid beetles on arable fields in northern Germany (Schleswig-Holstein) and their value as ecological indicators. - Agriculture, Ecocyctems and Environment 98: 141-151.

Kirschenhofer, E. 1989. Carabidae. In: Koch, K. (ed.): Die Käfer Mitteleuropas. Ökologie 1. — Goecke \& Evers. Krefeld. 440 pp.

Kutasi, Cs. 1998. Futóbogarak (Coleoptera, Carabidae) Litér környékéről. (Ground beetle (Coleoptera: Carabidae) of the environment of Litér (West Hungary).) - Folia Musei Historico-naturalis Bakonyiensis 13 (1994): 73-88. [In Hungarian.]

Kutasi, Cs., Harmat, B., Kasper, Á. \& Galambos, I. 2000. Izeltlábúak (Arthropoda) monitorozása dolomitgyepekben és telepített fenyvesekben. (Monitoring of the Arthropoda in dry grasslands of dolomite bedrock and in timbered pine-wood.) - Acta Biologica Debrecina, Oecologica Hungarica 11 (1): 257. [In Hungarian.]

Kutasi, Cs., Markó, V. \& Balog, A. 2004. Species composition of carabid (Coleoptera: Carabidae) communities in apple and pear orchards in Hungary. - Acta Phytopathologica et Entomologica Hungarica 39 (13): 71-89.

Lövei, G. L. \& Sárospataki, M. 1990. Carabid beetles in agricultural field in Eastern Europe. - In: Stork, N. E. (ed.): The Role of Ground Beetles in Ecological and Environmental Studies: 87-93. Intercept, Andover.

Müller-Motzfeld, G. 1989. Laufkäfer (Coleoptera: Carabidae) als pedobiologische Indicatoren. - Pedobiologia 33: 145-153.

Podani, J. 1997. SYN-TAX 5.1: A new version for PC and Macintosh computers. - Coenoses 12: 149-152.

Szél, Gy. \& Ádám, L. 1992. Bogárközösségek vizsgálata dolomitgyepekben (Coleoptera). (Examinations on beetle-communities in dolomitic grasslands (Coleoptera).) - Folia Entomologica Hungarica 52: 232-235. [In Hungarian.]

Szél, Gy. \& Kutasi, Cs. 2003. Tihanyi élöhelyek bogárfaunisztikai vizsgálata. (Coleopterological investigations in 17 habitats of the Tihany Peninsula). — Folia Musei Historico-naturalis Bakonyiensis 20 (20012003): 77-106. [In Hungarian.]

Szél, Gy. \& Kutasi, Cs. 2005. Influence of land-use intensity on the ground beetle assemblages (Coleoptera: Carabidae) in Central Hungary. - In: Lövei, G. \& Toft, S. (eds.): European Carabidology 2003. Proceedings of the $11^{\text {th }}$ European Carabidologist Meeting: 137-144. DIAS Reports Plant Production 114.

Thiele, H.-U. 1977. Carabid beetles in their environments. - Springer-Verlag, Berlin, Heidelberg, New York. $369 \mathrm{pp}$.

Turin, H., Penev, L. \& Casale, A. (eds.) 2003: The genus Carabus in Europe. - Pensoft, Sofia-Moscow. 511 pp.

Waliczky, Z. 1991. Guild structure of beetle communities in three stages of vegetational succession. - Acta Zoologica Academiae Scientiarum Hungaricae 37: 313-324. 